Jurnal Value, 16 (2), Hal. 499 - 511

p-ISSN: 1979-0643

e-ISSN: 2685-7324

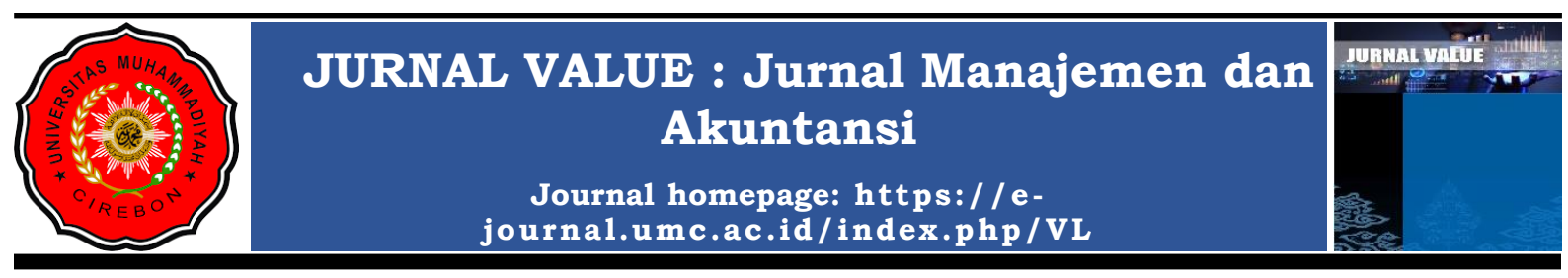

PENINGKATAN MINAT BELI KONSUMEN SECARA ONLINE DALAM APLIKASI E-COMMERCE

\author{
Sella Seftila ${ }^{1}$ \\ Oyon Saryono ${ }^{2}$ \\ Faizal Haris Eko Prabowo ${ }^{3 *}$ \\ ${ }^{1}$ Fakultas Ekonomi Universitas Galuh \\ Email : sellaseftila12@gmail.com \\ ${ }^{2}$ Fakultas Ekonomi Universitas Galuh \\ Email : oyonsaryono@gmail.com \\ ${ }^{3}$ Fakultas Ekonomi Universitas Galuh \\ *Corresponden Author Email : faizalharisekoprabowo@unigal.ac.id
}

Diterima : 3 September $2021 \quad$ Direvisi : 8 September 2021

Dipublikasikan : 31 Desember 2021

\begin{abstract}
Abstrak
Lebih rendanhnya tingkat minat beli secara online pada Mahasiswa Fakultas Ekonomi Universitas Galuh lebih dibanding minat beli secara offline. Diprakarsai ketika melakukan pembelian secara dengan adanya beberapa kendala saat transaksi. Hal ini dikarenakan konsumen memiliki pengalaman yang buruk sehingga minat beli secara online menjadi rendah. Adapaun tujuan penelitian adalah untuk mengetahui pengaruh kepercayaan konsumen dan pengalaman berbelanja terhadap minat beli secara online pada Mahasiswa Fakultas Ekonimi Universitas Galuh Ciamis. Metode yang digunakan pada penelitian ini adalah metode kuantitatif. Jumlah populasinya sebanyak 2345 dan sampel sebanyak 234 dengan menggunakan teknik sampling simple random, sedangkan untuk menganalisis data yang diperoleh digunakan Analisis Regresi Linear Berganda. Hasil dari penelitian dan pengolahan data menunjukan bahwa kepercayaan konsumen dan pengalaman berbelanja memiliki pengaruh positif terhadap minat beli secara online pada Mahasiswa Fakultas Ekonimi Universitas Galuh Ciamis dengan besarnya pengaruh sebesar 38,44 \% sementara 61,56\% dipengaruhi oleh faktor lain. Diharapkan situs belanja online mampu meningkatkan jaminan produk dengan menggunakan asuransi sehigga konsumen merasa percaya untuk melakukan transaksi pembelian dan memiliki pengalaman berbelanja yang baik agar minat beli secara online akan meningkat.
\end{abstract}

Kata Kunci: Kepercayaan Konsumen, Pengalaman Berbelanja, Minat Beli Online

\title{
PENDAHULUAN
}

Era revolusi industri 4.0 yang semakin berkembang seperti saat ini, internet merupakan hal yang tidak asing untuk masyarakat di dunia. Internet membawa perubahan yang signifikan pada masyarakat dalam berbagai aspek kehidupan. Saat ini internet mengalami perkembangan yang sangat cepat. Peran internet tidak hanya digunakan sebagai penyedia informasi namun juga banyak dimanfaatkan sebagai media dalam melakukan transaksi melalui berbagai macam situs marketplace dalam sebuah jaringan bisnis online yang dapat diakses dengan mudah. Marketplace merupakan sebuah tempat jaringan online dimana penjual dapat membuat akun dan menjajakan barang dagangannya secara online. 
Gambar 1.

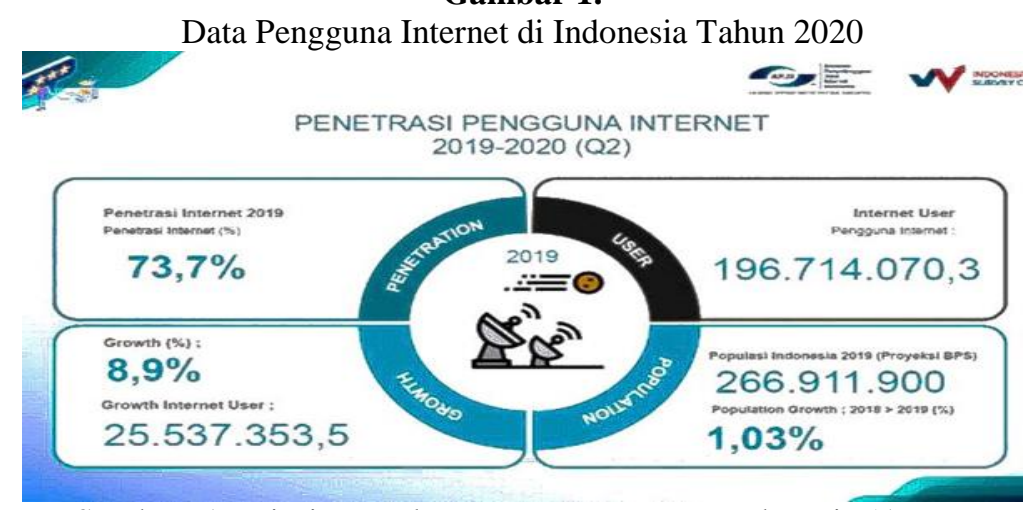

Sumber: Asosiasi Penyelenggara Jasa Internet Indonesia (APJII)

Berdasarkan Gambar 1. survei Asosiasi Penyelenggara Jasa Internet Indonesia (APJII) hingga kuartal II tahun 2020, jumlah pengguna internet di Indonesia terus tumbuh dari tahun ke tahun. Jumlah pengguna internet Indonesia ada 196,7 juta orang atau 73,7\% dari total populasi 266,9 juta penduduk Indonesia berdasarkan data BPS. Angka tersebut mengalami kenaikan sebesar 8,9\% atau setara dengan 25,5 juta pengguna dari periode yang sama tahun sebelumnya. Dengan meningkatnya teknologi internet dan banyaknya jumlah pengguna internet di Indonesia, maka menjadi sebuah peluang pasar yang baik bagi pelaku bisnis yang mulai menggunakan internet. Hal tersebut dapat mempermudah untuk melakukan promosi maupun perdagangannya dalam menjalankan bisnis e-commerce. E-commerce atau electronic commerce merupakan sebuah transaksi bisnis yang terjadi dalam jaringan elektonik seperti internet (Wong, 2010). Siapapun dapat mengaksesnya melalui komputer atau perangkat sejenisnya dan memiliki sambungan ke internet, serta mempunyai cara untuk membayar barang atau jasa yang mereka beli maka dapat berpartisipasi dalam e-commerce. Sedangkan (Kotler \& Keller, 2012) menjelaskan mengenai $e$ commerce adalah penggunaan website untuk bertransaksi atau memfasilitasi penjualan produk dan jasa secara online dapat juga dijadikan alat untuk membeli dan menjual produk atau jasa melalui internet dengan menggunakan sistem komputer untuk meningkatkan efisiensi perusahaan secara keseluruhan. Biasanya terdiri dari perdagangan yang terjadi melalui pembeli mengunjungi website penjual dan transaksi online. Saat ini semakin banyak situs marketplace yang bermunculan yang dijadikan sebagai tempat untuk menjual atau membeli barang dan jasa secara online. Belanja secara daring saat ini telah menjadi pola hidup baru di masyarakat dalam beberapa tahun ini. Banyaknya penjual yang menyediakan berbagai macam produk yang ditawarkan melalui toko online membuat minat beli di masyarakat khususnya pengguna internet berubah. Dengan adanya teknologi belanja online telah membantu konsumen memenuhi kebutuhan tanpa harus menggunakan banyak waktu dari mulai sruvei, mencari hingga membeli. Berdasarkan data pada gambar 1.2 hasil survei Data Tempo pada Kuartal I tahun 2020, tercatat ada 10 situs e-commerce di Indonesia yang sering digunakan. Urutan 10 besar situs e-commerce tersebut yaitu Shopee, Tokopedia, Bukalapak, Lazada Indonesia, Blibli, JD.id, Orami, Bhinneka, Siciolla, dan yang terakhir Zalora Indonesia.

Gambar 2.

Pengguna E-commerce Terbesar di Indonesia

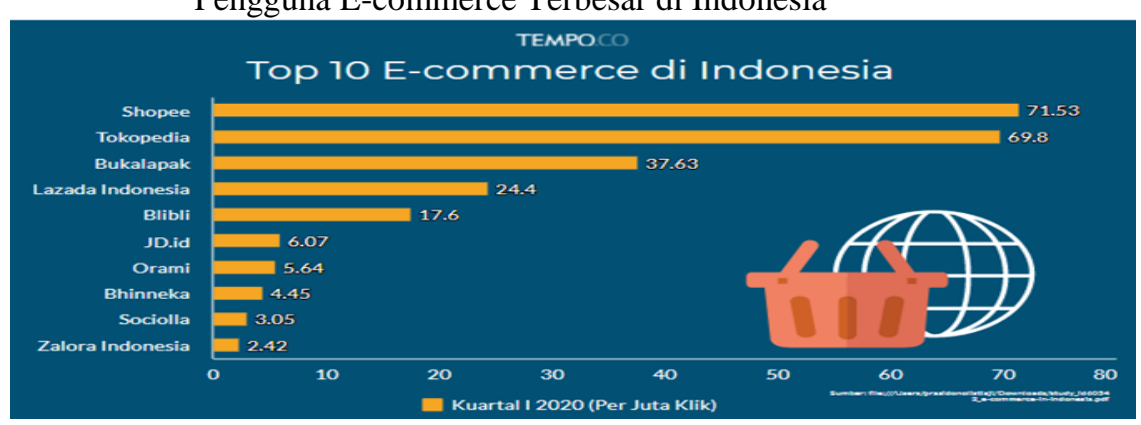

Sumber: https://data.tempo.co/data/907/top-10-e-commerce-di-indonesia-kuartal-i-2020 
Jurnal Value, 16 (2), Hal. 499 - 511

Adanya e-commerce telah memberikan kemudahan konsumen. Konsumen tidak perlu datang langsung ke toko, mereka cukup mengaksesnya melalui situs marketplace dan memilih barang atau jasa yang dibutuhkan secara online. Kemudian dalam melakukan pembayaran, pembeli dapat mentransfer total pembelian ke penjual dengan menggunakan kartu kredit, bank transfer, COD (Cash On Delivery), atau bisa juga melakukan pembayaran melalui minimarket. Selain itu untuk menarik minat beli secara online, penjual memberikan berbagai macan tawaran. Seperti banyaknya diskon yang diberikan di situs marketplace, tersedianya voucher gratis ongkos kirim dalam pengiriman barang secara online sehingga tidak menambah biaya pembelian, serta produk yang tersedia harganya lebih murah dibanding toko offline.

Pada belanja online minat pembelian merupakan prediktor penting dari perilaku pembelian aktual yang mengacu pada hasil penilaian konsumen mengenai pencarian informasi, kualitas produk dan evaluasi produk yang selanjutnya akan menghasilkan peningkatan minat pembelian dan memungkinkan untuk mendorong suatu keputusan pembelian dalam sebuah produk (Putri, 2016). Minat beli merupakan faktor yang penting dalam dunia bisnis karena keputusan konsumen untuk membeli sebuah produk didasari dengan adanya minat dan minat muncul ketika ada stimulus positif yang dapat menimbulkan motivasi untuk membeli produk atau jasa di masa depan (Jalilvand, 2013). Pada penelitian ini, tim peneliti memilih mahasiswa di fakultas eknomi universitas Galuh sebagai respondennya karena dapat mewakili pasar dengan kategori generasi $\mathrm{Z}$ yang sering menggunakan aplikasi berbelanja secara daring. Dengan karakteristik responden ini dapat mewakili populasi yang digunakan pada penelitian ini. Peneliti melakukan kegiatan pra-penelitian dengan melihat minat, intensitas dan keluhan saat melakukan transaksi di aplikasi ecommerce. Untuk lebih sepsifiknya disajikan dalam gambar berikut:

\section{Gambar 3.}

Minat Beli Secara Online Pada Mahasiswa Fakultas Ekonomi Univerisitas Galuh

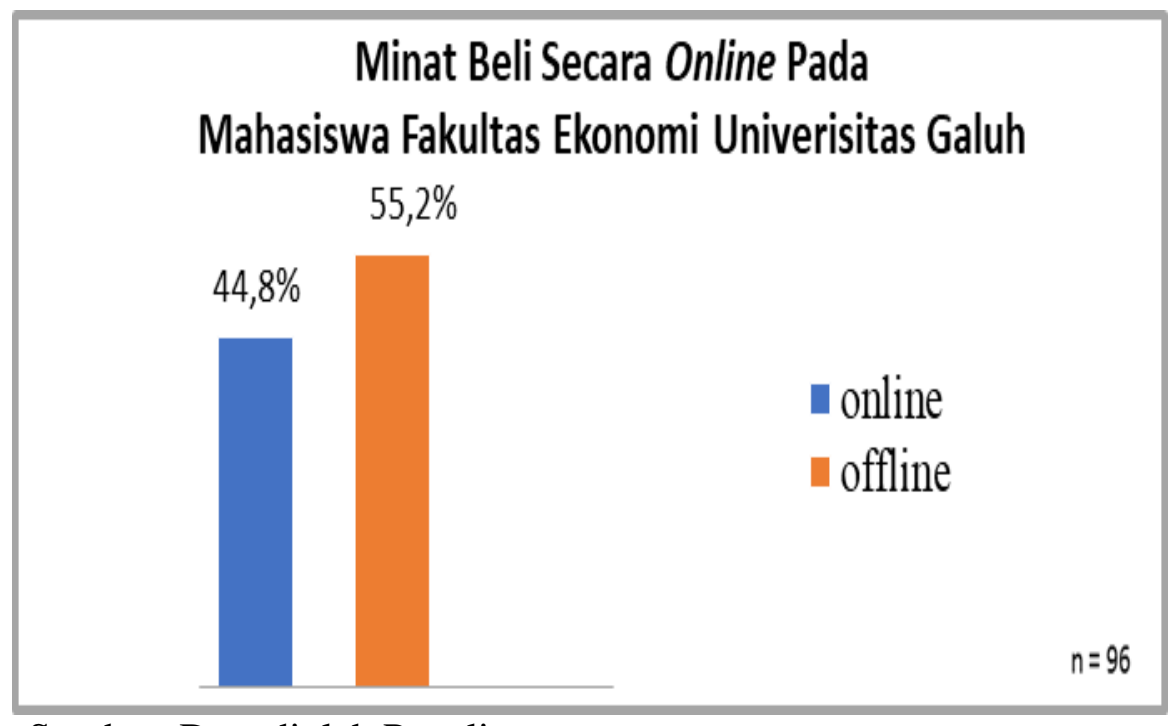

Sumber: Data diolah Penulis

Berdasarkan Gambar 3 hasil survei kepada Mahasiswa Fakultas Ekonomi Univeritas Galuh dengan sampel sebanyak 96 orang menjunjukan bahwa minat beli secara online lebih rendah dibanding minat beli secara offline. Dari hasil survei tersebut terbukti bahwa ada 44,8\% mahasiswa Fakultas Ekonomi Universitas Galuh yang berminat melakukan pembelian secara online. Dan sisanya sebanyak 55,2\% lebih berminat melakukan pembelian secara offline. Sedangkan pada Gambar 1.3 merupakan data intensitas transaksi secara online. Dimana dalam satu bulan terdapat $45,8 \%$ yang melakukan transaksi secara online sebanyak dua hingga tiga kali, 29,2\% melakukan transaksi secara online sebanyak satu kali, dan 25\% melakukan transaksi secara online lebih dari tiga kali. Dari hasil pra-penelitian didapatkan data yang berbelanja online lebih sedikit dibandingkan dengan berbelanja secara offline. Selanjutnya data prapenelitian mengenai intensitas transaksi online digambarkansebagai berikut: 
Jurnal Value, 16 (2), Hal. 499 - 511

Gambar 4.

Intensitas Transaksi Online Per-Bulan Pada Mahasiswa Fakultas Ekonomi Universitas Galuh

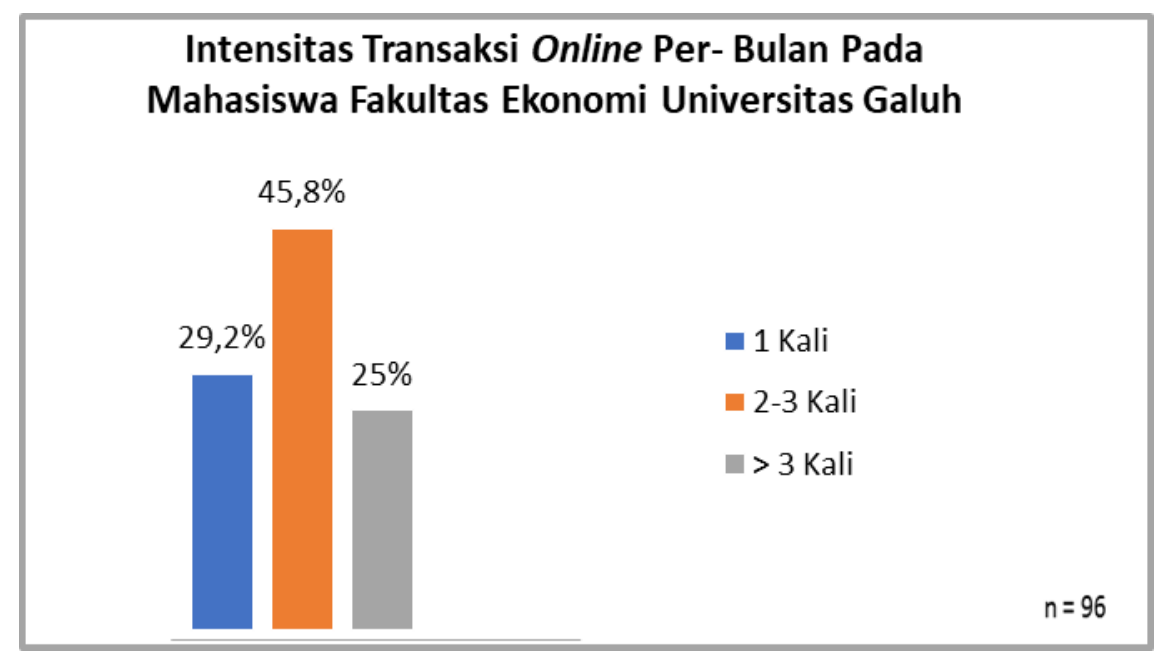

Sumber: Data diolah Penulis

Meskipun banyak tawaran menggiurkan yang diberikan oleh situs marketplace terhadap konsumen, akan tetapi sebagian besar mahasiswa Fakultas Ekonomi Universitas Galuh lebih berminat melakukan pembelian secara offline dibanding melakukan pembelian secara online. Hal ini disebabkan karena mereka pernah mengalami permasalahan ketika melakukan pembelian secara online. Dimana dalam melakukan pembelian online kualitas barang yang dibeli nyatanya tidak sesuai dengan foto dan deskripsi yang terpampang di toko online tersebut. Selain itu ada penjual yang tidak jujur dan melakukan penipuan dengan kedok jual beli online, proses pengiriman barang yang dilakukan oleh penjual yang cenderung lama dan waktunya tidak sesuai estimasi. Dan yang lebih parahnya meraka pernah mengalami barang yang dibeli tidak kunjung sampai karena tidak dikirim oleh penjual, serta data pribadi disalah gunakan oleh oknum penjual tersebut. Berikut adalah data kasus dalam pembelian secara online pada mahasiswa Fakultas Ekonomi Universitas Galuh:

Gambar 5.

Kasus Pembelian Secara Online Pada Mahasiswa Fakultas Ekonomi Universitas Galuh

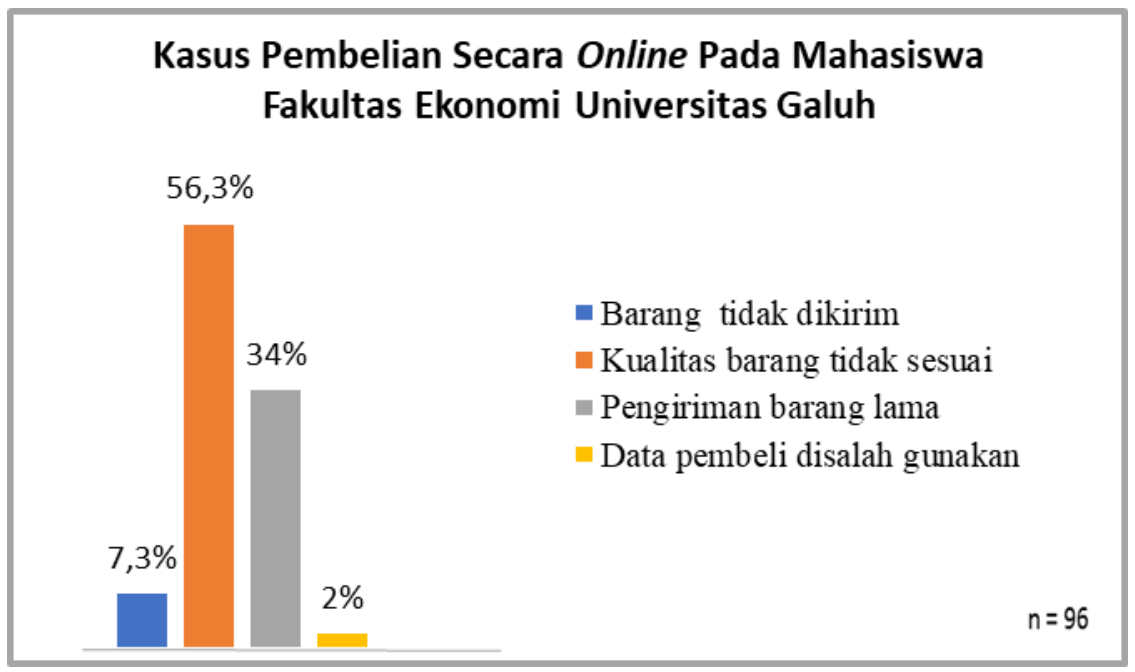

Sumber: Data diolah Penulis 
Banyaknya hal buruk yang pernah dialami oleh mahasiswa Fakultas Ekonomi Univeritas Galuh ketika melakukan pembelian secara online akan menimbulkan dampak negatif bagi para pelaku ecommerce. Konsumen akan merasa takut untuk melakukan pembelian secara online. Kemudian penjual akan kehilangan konsumen dan minat beli secara online akan rendah. Hal tersebut sangat erat kaitannya dengan kepercayaan konsumen dan pengalaman berbelanja sebelumnya. Untuk itu para pelaku e-commerce harus mampu meningkatkan kualitas keamanan dan pelayanan di toko online tesebut agar dapat meningkatkan minat beli secara online. Selain itu, faktor kepercayaan menjadi kunci dalam setiap proses pembelian secara online. Hanya pelanggan yang memiliki kepercayaan tinggi yang akan melakukan pembelian secara online. Karena itu jika tidak ada landasan kepercayaan antara penjual dan pembeli maka tidak akan terjadi sebuah transaksi dalam dunia e-commerce. Menurut Pavlou dan Geffen dalam penelitian (Baskara dan Haryadi, 2014) bahwa "Faktor yang sangat penting yang dapat mempengaruhi seseorang dalam pembelian secara online adalah kepercayaan". Kepercayaan menjadi salah satu faktor penentu dalam setiap transaksi jual beli secara online. Dengan adanya sebuah kepercayaan, maka konsumen akan berminat untuk melakukan pembelian secara online.

Beberapa penelitian terdahulu yang mnegkaji mengenai minat beli konsumen telah dipelajari oleh banyak peneliti, pada beberapa penelitian bukan hanya faktor kepercayaan saja yang menjadi tolak ukur konsumen dalam menarik minat beli secara online. Pengalaman berbelanja juga merupakan salah satu hal yang selalu dijadikan pertimbangan, karena pengalaman sebelumnya akan sangat mempengaruhi perilaku dimasa depan. Pelanggan dengan minat pembelian online yang kuat pada situs belanja online biasanya mempunyai pengalaman pembelian yang sebelumnya dapat membantu mengurangi ketidakpastian (Ling et. al., 2010). Oleh sebab itu, pelanggan hanya akan membeli produk secara online setelah mereka memiliki pengalaman sebelumnya yang baik. Jika sebuah pengalaman pembelian secara online hasilnya memuaskan, maka akan menyebabkan pelanggan untuk terus berbelanja di internet dalam jangka waktu yang panjang (Ling et al., 2010). Adapun penelitian yang mengkaji mengenai kepercayaan konsumen berpengaruh positif dan signifikan terhadap minat beli produk pakaian secara online (Rosdiana et. al., 2018). Sedangka npada penelitian lain mengemukakan bahwa terdapat pengaruh yang signifikan antara pengalaman berbelanja dan kepercayaan konsumen terhadap minat beli konsumen pada situs jual beli online Tokopedia.com (Paramasatya, 2018).

Berdasarkan uraian tersebut maka penulis tertarik untuk mengetahui lebih jauh mengenai sebarapa besar pengaruh kepercayaan konsumen dan pengalaman berbelanja terhadap minat beli secara online pada mahasiswa Fakultas Ekonomi Universitas Galuh. Peneliti mencoba untuk membangun hipotesis sebagai berikut: $\mathrm{H}_{1}$ : Kepercayaan konsumen memiliki pengaruh terhadap minat beli. Hal ini dikarenakan adanya korelasi yang terbangun ketika seorang konsumen memiliki kepercayaan yang cukup tinggi pada sebuah brand atau perusahaan, maka ada kemungkinan mereka memiliki niat untuk membeli. Hanya saja ada beberapa rintangan hingga menuju proses transaksi, kemungkinan bisa terjadi kesesuaian kebutuhan pasar dengan produk yang ditawarkan tetapi apakah konsumen dapat menyesuaikan harga yang ditawarkannnya, lalu layanan purna jualnya, nilai dari produk tersebut, dan masih banyak lagi rintangannya. Selanjutnya, hipotensis yang kedua adalah: $\mathrm{H}_{2}$ : Pengalaman berbelanja memiliki pengaruh terhadap minat beli. Pengalaman berbelanja merupakan hal yang paling utama dilakukan oleh konsumen pada saat ingin mencoba layanan atau produk baru yang mungkin konsumen memiliki ketidakpercayaan saat pertama kali mencobanya. Pengalaman berbelanja ini tidak harus membeli dengan nilai transaksi besar melainkan mencoba dengan transaksi yang nilainya cukup rendah atau bahkan sangat rendah. Dari pengalaman berbelanja ini konsumen memiliki minat yang lebih tinggi lagi dari sebelumnya. Terakhir hipotesis yang dicoba untuk dibangun adalah $\mathrm{H}_{3}$ : Kepercayaan konsumen dan Pengalaman berbelanja Memiliki pengaruh terhadap Minat Beli. Penggabungan kepercayaan dan pengalaman dapat memiliki korelasi untuk meningkatkan minat beli. Minat beli merupakan tahapan dimana konsumen akan melakukan transaksi, tahapan ini merupakan tahapan yang cukup krusial bagi perusahaan karena pada tahapan ini konsumen masih bisa diberikan stimulus dari merek-merek lain. Maka dari itu meningkatkan konsumen dan memberikan pengalaman berbelanja yang baik disinyalir memiliki dampak pada minat beli seorang konsumen. 
Jurnal Value, 16 (2), Hal. 499 - 511

\section{KAJIAN PUSTAKA Kepercayaan Konsumen}

Dalam sebuah situs online, membangun sebuah kepercayaan merupakan hal yang relatif sulit. Perusahaan dapat memberlakukan peraturan yang ketat kepada mitranya, begitupun dengan pembeli khawatir mereka tidak mendapatkan produk ataupun jasa sesuai dengan kualitas yang baik dan menerima pesanan pada waktu yang tepat. Kepercayaan menurut (Firdayanti, 2012) adalah "Kepercayaan konsumen merupakan sebuah presepsi dari sudut pandang konsumen terhadap keandalan seorang penjual dalam terciptanya harapan dan kepuasan konsumen". Kepercayaan konsumen menurut (Sumarwan, 2013) adalah "Kepercayaan konsumen adalah pengetahuan konsumen mengenai suatu objek, atributnya dan manfaatnya". Pengertian kepercayaan konsumen menurut (Mowen, 2011) adalah "Kepercayaan konsumen adalah semua pengetahuan yang dimiliki oleh konsumen dan semua kesimpulan yang dibuat konsumen tentang objek, atribut dan manfaatnya”. Salah satu faktor yang sangat penting dan bisa mempengaruhi seseorang dalam minat pembelian dan dapat menimbulkan keputusan pembelian secara online oleh konsumen adalah faktor kepercayaan, Pavlou dan Geffen dalam (Baskara dan Hariyadi, 2014), sedangkan (Andromeda, 2015) menjelaskan kepercayaan konsumen terhadap website online shopping terletak pada popularitas website online shopping itu sendiri. Semakin baik suatu situs website maka konsumen akan lebih yakin terhadap kualitas dan reliabilitas website tersebut.

Dimensi kepercayaan konsumen meliputi tiga faktor, yaitu keamanan, Privasi dan keandalan (Ikranegara, 2017). Keamanan dapat diartikan sejauh mana seorang pelanggan percaya bahwa transaksi jual beli secara online aman bagi mereka untuk mengirimkan sebuah informasi dalam tranasksi bisnis. Keamanan memiliki peranan yang sangat penting dalam mempengaruhi minat beli secara online karena memiliki resiko transmisi informasi seperti alamat rumah, nomor telepon, nomor rekening, dan lain-lain. Privasi dapat diartikan sebagai sikap dalam menjaga segala perilaku seorang konsumen dalam melakukan transaksi yang berkaitan dengan kinerja toko online. Keandalanan dalam perusahaan dapat mempengaruhi kepercayaan konsumen, dimana sebagian besar konsumen menganggap bahwa perusahaan besar memiliki kemampuan yang lebih baik dalam meningkatkan kepercayaan online mereka. Pengukuran kepercayaan konsumen dinilai berdasarkan Keamanan, Privasi dan Keandalan (Ling et al, 2010). Hal yang penting bagi kesuksesan relationship adalah kepercayaan, kepercayaan sendiri memiliki manfaat bagi perusahaan yang memiliki konsumennya seperti Kerjasama (cooperation), dengan meningkatkan kepercayaan kerjasama memberikan hasil yang lebih banyak dibandingkan apabila dikerjakan sendiri. Kemudian, Komitmen (commitment).

Selanjutnya, Komitmen akan dibentuk hanya dengan pihak-pihak yang saling percaya karena komitmen merupakan komponen yang dapat membangun hubungan. Yang ketiga, Durasi hubungan (relationship duration) Kemungkinan bahwa pembeli akan terlibat dalam bisnis pada masa yang akan datang berhubungan dengan kepercayaan dari penjual secara positif, hal itu memberikan kontribusi untuk meningkatkan durasi hubungan. Terakhir, Kualitas (quality). Informasi yang diberikan pihak yang dipercaya lebih mungkin untuk diterima oleh pihak yang percaya, dan dalam informasi tersebut akan menghasilkan benefit yang lebih besar. Akhirnya perselisihan atau konflik kemungkinan dapat dipecahkan dengan damai oleh kepercayaan, perselisihan merupakan penyebab berakhirnya relationship dan tanda akan adanya kesulitan pada masa yang akan datang (Priansa, 2017). Terdapat tiga jenis kepercayaan konsumen yaitu Kepercayaan Atribut Objek, Kepercayaan Manfaat Produk dan Kepercayaan Manfaat Objek (Priansa, 2017). Adapun hipotesis yang dirancang pada peubah ini adalah sebagai berikut:

$\mathrm{H}_{1}$ : Kepercayaan konsumen memiliki pengaruh terhadap minat beli

\section{Pengalaman Berbelanja}

Online shopping merupakan suatu kegiatan yang terbilang baru dan dianggap lebih beresiko daripada membeli secara langsung. Konsumen web shopping akan bergantung pada kualitas pengalaman dimana hal tersebut dapat diperolehnya ketika melakukan pembelian sebelumnya, (Laudon dan Carol, 2015). Pengalaman adalah pembelajaran yang mempengaruhi perubahan perilaku seseorang yang meliputi pengalaman konsumen, informasi, pengalaman bertransaksi (Kotler \& Keller, 2012). Pengalaman dapat dibagi menjadi dua jenis, pertama pengalaman yang mengacu pada masa lalu (mengacu pada pengetahuan 
dan akumulasi pengalaman dari waktu ke waktu) dan kedua mengacu pada presepsi yang sedang berlangsung, perasaan dan observasi langsung (Sumarwan, 2015). Konsumen yang tidak memiliki kepercayaan dengan pengecer online akan kurang percaya diri dalam berbelanja di internet karena kurangnya pengalaman berbelanja dengan pengecer tersebut (Sumarwan et. al., 2013). Terdapat empat dimensi dalam pengalaman berbelanja, yaitu Berpengalaman dalam berbelanja online, Merasa berkompeten ketika berbelanja online, Merasa nyaman ketika menggunakan web belanja dan Merasa bahwa situs online mudah digunakan (Ling. et. al., 2010).

Pengukuran atau indikator pengalaman berbelanja yang dirasakan oleh konsumen diukur dari berpengalaman dalam berbelanja online, merasa berkompeten ketika berbelanja online, merasa nyaman ketika menggunakan web belanja dan merasa bahwa situs online mudah digunakan (Ling et al, 2010). Terdapat enam aspek yang dapat dirasakan dalam proses pengalaman konsumen yaitu: Sensorik. Penglihatan pendengaran, sentuhan, rasa, dan bau yang membangkitkan kenikmatan estetis, kegembiraan, kepuasan dan rasa keindahan. Emosional. Suasana hati, perasaan dan pengalaman emosional yang membuat hubungan efektif dengan perusahaan, merek dan produk. Kognitif. Pengalaman terkait dengan pemikiran dan proses kesadaran mental konsumen dalam menggunakan kreativitas mereka atau pemecahan masalah sehingga merevisi tentang asusmsi sebuah produk. Pragmatis. Pengalaman yang dihasilkan dari tindakan praktis dalam melakukan sesuatu. Gaya hidup. Pengalaman yang dihasilkan dari penegasan nilainilai dan keyakinan pribadi. Relasional. Pengalaman yang muncul dari konteks hubungan sosial konsumen yang umum terjadi selama mengkonsumsi sebuah produk sebagai bagian dari komunitas untuk menegaskan identitas sosial konsumen (Schmitt, 2010). Adapun hipotesis yang dirancang pada peubah ini adalah sebagai berikut:

$\mathrm{H}_{2}$ : Pengalaman berbelanja memiliki pengaruh terhadap minat beli

\section{Minat Beli}

Minat beli adalah keinginan untuk membeli produk, minat beli akan timbul apabila seorang konsumen sudah terpengaruh terhadap mutu dan kualitas dari suatu produk, informsai seputar produk (Durianto, 2013). Minat beli adalah Minat beli adalah perilaku konsumen yang muncul sebagai respon terhadap suatu objek yang menunjukan keinginan seseorang untuk melakukan pembelian (Kotler dan Keller, 2012). Minat pembelian merupakan suatu model dan sikap seseorang terhadap objek barang yang sangat cocok dalam mengukur sikap terhadap suatu golongan produk, jasa ataupun merek tertentu (Schiffman dan Kanuk, 2010). Menurut Minat pembelian konsumen bisa diukur dalam tiga dimensi seperti ketertarikan, perhatian dan Pencarian Informasi (Astuti, 2010). Ketertarikan konsumen dalam minat beli merupakan salah satu indicator yang dapat menimbulakn rasa senang dan puas dalam diri seseorang sehingga mampu membangkitkan rasa ingin membeli. Perhatian merupakan keaktifan pikiran, akal dan ingatan yang dapat membangkitkan rasa ingin membeli. Pencarian informasi yaitu adanya rasa ingin tahu yang dapat membangkitkan rasa ingin membeli. Indikator minat beli dinilai oleh ketertarikan, perhatian dan pencarian Informasi (Astuti, 2010).

Minat beli dapat diidentifikasi melalui aspek-aspek sebagai berikut: Minat transaksional yaitu kecenderungan seseorang untuk membeli produk. Hal ini bermaksud yakni konsumen telah memiliki minat untuk melakukan pembelian suatu produk tertentu yang ia inginkan. Minat referensial, yaitu kecenderungan seseorang untuk mereferensikan produk kepada orang lain. Hal ini bermaksud yakni seorang konsumen yang telah memiliki minat untuk membeli akan menyarankan orang terdekatnya untuk juga melakukan pembelian produk yang sama. Minat preferensial, yaitu minat yang menggambarkan perilaku seseorang yang memiliki preferensi utama pada produk tersebut. Preferensi ini hanya dapat diganti jika terjadi sesuatu dengan produk preferensinya. Minat eksploratif yaitu menggambarkan perilaku seseorang yang selalu mencari informasi mengenai produk yang diminatinya dan mencari informasi untuk mendukung sifat-sifat positif dari produk tersebut (Ferdinand, 2002). Adapun hipotesis yang dirancang untuk peubah ini adalah sebagia berikut:

$\mathrm{H}_{3}$ : Kepercayaan konsumen dan Pengalaman berbelanja Memiliki pengaruh terhadap Minat Beli 
Jurnal Value, 16 (2), Hal. 499 - 511

\section{METODE PENELITIAN}

Metode yang digunakan pada penelitian ini adalah metode kuantitatif dengan strategi survei. Peubah yang diamati pada penelitian ini sebanyak tiga, dengan susunan kepercayaan, pengalaman berbelanja dan minat beli. Kegiatan penelitian ini dimulai dari awal dengan penyusunan rencana penelitian, lalu dilanjutkan dengan mencari data pra survei untuk dijadikan acuan sebagai bahan penelitian. Setelah itu merancang kajian pustaka, perancangan metode dan perumusan hipotesis. Selanjutnya pengumpulan data ke lapangan dengan dilanjutkan untuk merancang penyajian hasil penelitian dan pembahasan yang telah dianalisis. Kepercayaan diukur dengan menggunakan keamanan, orivasi dan keandalan (Ling et al 2010). Pengalaman berbelanja diukur dengan menggunakan memiliki pengalaman dalam berbelanja, merasa kompeten dalam berbelanja, merasa nyaman saat berbelanja dan merasa bahwa situs atau aplikasi mudah digunakan (Ling et al), sedangkan pengukuran minat beli menggunakan ketertarikan, perhatian dan pencarian Informasi (Astuti, 2010).

Dalam penyusunan kuesioner peneliti merancang sendiri pernyataan dalam kuesioner tidak melihat penelitian lain. Populasi dalam penelitian menggunakan mahasiswa fakultas ekonomi universitas galuh yang pernah berbelanja secara daring, untuk menemukan populasi ini peneliti memberikan kuesioner dengan isi jika mereka merupakan pengguna e-commerce maka pengisian kueionernya dilanjutkan, tetapi jika bukan pengguna e-commerce maka tidak perlu dilanjutkan. Jumlah populasi dalam penelitian ini sebanyak 2345 mahasiswa dengan diambil sampel sebanyak 234 mahasiswa sebagai responden dari seluruh angkatan. Sampel diambil berdasarkan perhitungan total populasi diambil sebanyak $10 \%$ nya. Sumber data yang digunakan adalah data primer dan sekunder, data primer digunakan untuk mencari data utama untuk dianalisis dengan statistik sedangkan data sekunder berupa data yang telah disediakan oleh pihak ketiga seperti data pengguna situs atau aplikasi berbelanja. Teknik pengumpulan datanya menggunakan kuesioner yang disebarkan ke sampel, sebelum intrumen penelitian ini digunakan diuji terlebih dahulu validitas dan reliabilitasnya dan hasilnya menunjukan seluruh pernyataan valid dan seluruh variabel reliabel. Teknik analisis data yang digunakan adalah Analisis regresi linear berganda, teknik analisis data ini digunakan karena untuk mengukur variabel bebas yang mempengaruhi diperlukan pengukuran ganda. Penelitian ini dilakukan dari november 2020 hingga juni 2021 di Fakultas Ekonomi Universitas Galuh. Tempat ini berlokasi di Provinsi Jawa Barat, Kabupaten Ciamis.

\section{HASIL DAN PEMBAHASAN}

Perhitungan analisis regresi linear berganda variabel Kepercayaan konsumen $\left(\mathrm{X}_{1}\right)$ dan Pengalaman Berbelanja $\left(\mathrm{X}_{2}\right)$ terhadap Minat Beli (Y):

$$
\begin{aligned}
& b_{1}=\frac{\left(\Sigma x_{2}^{2}\right)\left(\sum x_{1} y\right)-\left(\sum x_{1} x_{2}\right)\left(\Sigma x_{2} y\right)}{\left(\sum x_{1}^{2}\right)\left(\Sigma x_{2}^{2}\right)-\left(\sum x_{1} x_{2}\right)^{2}} \\
& =\frac{(891,33)(263,63)-(480,75)(264,33)}{(398,41)(891,33)-(480,75)^{2}} \\
& =0,482519903 \\
& =0,48 \\
& b_{2}=\frac{\left(\sum x_{1}^{2}\right)\left(\Sigma x_{2} y\right)-\left(\sum x_{1} x_{2}\right)\left(\sum x_{1} y\right)}{\left(\sum x_{1}{ }^{2}\right)\left(\Sigma x_{2}{ }^{2}\right)-\left(\sum x_{1} x_{2}\right)^{2}} \\
& =\frac{(398,41)(364,33)-(480,75)(263,63)}{(398,41)(891,33)-(480,75)^{2}} \\
& =0,148495573 \\
& =0,15 \\
& a=\frac{\Sigma y-b_{1} \Sigma X_{1}-b_{2} \Sigma X_{2}}{n} \\
& =\frac{2380-(0,48 \cdot 2379)-(0,15 \cdot 3112)}{96}
\end{aligned}
$$


Jurnal Value, 16 (2), Hal. 499 - 511

$$
\begin{aligned}
& =\frac{2380-1141,92-466,8}{96} \\
& =\frac{771,28}{96} \\
& =8,03416667 \\
& =8,34
\end{aligned}
$$

Didapatkan Persamaan regresi linear berganda:

$$
\begin{aligned}
\mathrm{Y} & =\mathrm{a}+\mathrm{b} 1 \mathrm{X}_{1}+\mathrm{b} 2 \mathrm{X}_{2} \\
& =8,34+0,48 \mathrm{X}_{1}+0,15 \mathrm{X}_{2}
\end{aligned}
$$

Berdasarkan perhitungan analisis regresi diatas dapat diketahui persamaan regresinya yaitu $\mathrm{Y}=$ $8,34+0,48 \mathrm{X}_{1}+0,15 \mathrm{X}_{2}$ atau $\mathrm{Y}=8,34$ artinya apabila bobot $\mathrm{X}_{1}$ bertambah 1 maka bobot $\mathrm{Y}$ akan mengalami kenaikan sebesar 0,48, begitu juga dengan peningkatan $\mathrm{X}_{2}$ bertambah 1 maka bobot $\mathrm{Y}$ akan mengalami kenaikan sebesar 0,15. Sedangkan hasil koefisien dan t hitungnya disajikan pada tabel sebagai berikut:

Tabel 1. Hasil Regresi Linear Berganda

\begin{tabular}{cccc}
\hline Variabel & Koefisien & t hitung & koefisien determinasi \\
\hline Kepercayaan konsumen & 0.61 & 7.46 & $37.21 \%$ \\
\hline Pengalaman berbelanja & 0.56 & 3.56 & $31.36 \%$ \\
\hline
\end{tabular}

Sumber: Data diolah Penulis

Kepercayaan konsumen merupakan kunci terpenting karena aktivitas bidang usaha yang dijalankan adalah memalui situs jual beli online, penjual dan pembeli tidak berhadapan secara langsung. Kepercayaan merupakan unsur yang paling penting dan berkaitan dengan belanja online karena kepercayaan mampu memberikan dorongan bagi konsumen untuk senantiasa memberli suatu produk tertentu. Hasil penelitian terhadap situs belanja online pada mahasiswa Fakultas Ekonomi Universitas Galuh menunjukan bahwa variabel kepercayaan konsumen berpengaruh positif terhadap variabel minat beli. Hal tersebut dibuktikan dengan pencapaian skor hasil dari rekapitulasi responden mengenai kepercayaan konsumen sebesar 2.379 berada pada interval $2.304-2.880$ yang artinya bahwa tingkat kepercayaan konsumen pada situs belanja online sangat tinggi. Skor yang didapatkan merupakan skor hasil analisis deskriptif yang diambil dari kuesioner sebanyak 6 pernyataan, skor ini dihitung berdasarkan tanggapan sangat setuju dengan nilai 5 , setuju 4 cuikup setuju 3 tidak setuju 2 sangat tidak setuju 1. Pengaruh ini sangat menguntungkan bagi pelaku penjual online karena situs belanja online sudah teruji kepercayaannya dengan tingginya minat beli konsumen secara online. Itu artinya, semakin tinggi kepercayaan yang diberikan konsumen maka semakin tinggi pula minat yang timbul pada diri konsumen untuk melakukan pembelian secara online. Berdasarkan hal tersebut dapat disimpulkan bahwa faktor yang mempengaruhi minat beli konsumen untuk untuk membeli suatu produk melalui situs belanja online adalah kepercayaan.

Kepercayaan merupakan salah satu pondasi dari bisnis apapun, apalagi dalam situs belanja online tidak ada pertemuan antar penjual dan pembeli. Suatu transaksi bisnis antar dua belah pihak atau lebih akan terjadi apabila masing-masing pihak saling mempercayai. Kepercayaan konsumen dalam situs belanja onlie tidak begitu saja dapat diakui oleh pihak lain atau mitra bisnis, melainkan harus dibangun mulai daari awal dan dapat dibuktikan. Hasil tersebut dibuktikan dengan uji statistik analisis koefisien korelasi sederhana diperoleh angka sebesar 0,61. Hasil kuesioner tersebut dihitung berdasarkan perhitungan manual, dimana berdasarkan pedoman interpretasi koefisien korelasi termasuk kedalam hubungan yang kuat antara kepercayaan konsumen terhadap minat beli. Ketika seseorang berbelanja online, hal pertama yang menjadi pertimbangan konsumen adalah apakah meraka percaya kepada situs belanja online dan penjual online tersebut atau tidak. Hal tersebut sejalan dengan teori yang dikemukakan oleh (Ling et al, 2010) bahwa "Terbangunnya rasa percaya konsumen dan adanya rasa aman terhadap penjual maupun situs jual beli online dapat meningkatkan minat beli konsumen di situs tersebut". Berdasarkan hasil dari perhitungan manual koefisien determinasi didapatkan sebesar 37,21\%. Hal ini menunjukan bahwa pengaruh kepercayaan konsumen terhadap minat beli sebesar 37,21\% dan sisanya $62,79 \%$ dipengaruhi olah faktor 
lain. Hasil tersebut mengindikasikan jika kepercayaan konsumen memiliki dampak untuk meningkatkan minat beli pada situs belanja online. Kemudian berdasarkan uji t atau thitung diperoleh 7,46 dan ttabel diperoleh 1,66 dimana dari data tersebut menunjukan bahwa thitung $>$ ttabel $(7,46>1,66)$ maka hipotesis diterima, artinya terdapat pengaruh positif dan signifikan pada kepercayaan konsumen terhadap minat beli. Dengan demikian apabila kepercayaan konsumen terhadap situs belanja online itu baik, maka minat beli konsumen akan meningkat. Hal ini juga didukung oleh peneliti yang dilakukan oleh (Ikranegara, 2017) yang menyatakan bahwa kepercaayaan berpengaruh positif terhadap minat beli.

Konsumen dengan niat pembelian online yang kuat dalam berbelanja secaara online biasanya memiliki pengalaman pembelian sebelumnya yang dapat membantu mengurangi ketidak pastian mereka. Konsumen biasanya hanya akan membeli produk secara online setelah mereka mengalaminya. Konsumen yang memiliki pengalamaan berbelanja online sebelumnya akan lebih cenderung untuk membeli secara online daripada mereka yang tidak memiliki pengalaman berbelanja sama sekali. Pengalaman berbelanja sebelumnya akan sangat mempengaruhi perilaku konsumen di masa depan untuk menentukan minat beli secara online. Hasil penelitian terhadap situs belanja online pada mahasiswa Fakultas Ekonomi Universitas Galuh menunjukan bahwa variabel pengalaman berbelanja berpengaruh positif terhadap variabel minat beli. Hal tersebut dibuktikan dengan pencapaian skor hasil dari rekapitulasi responden mengenai pengalaman berbelanja dengan menggunakan analisis desktiptif sebesar 3.112 dan berada pada interval 3.072-3.840 yang artinya bahwa tingkat pengalaman berbelanja pada situs belanja online sangat tinggi. Dalam konteks belanja online, konsumen mengevaluasi pengalaman berbelanja mereka berdasarkan presepsi mengenai informasi produk, bentuk pembayaran, penggunaan web belanja, persyaratan pengiriman, layanan yang ditawarkan, kejujuran penjual, respon penjual, privasi, sitstem keamanan, daya tarik visual, serta kenyamanan pada situs berbelanja online. Oleh karena itu, pengalaman berbelanja menjadi penentu dalam menarik minat beli konsumen dalam berbelanja secara online. Berdasarkan uji statistik analisis koefisien korelasi sederhana diperoleh angka sebesar 0,56 dimana berdasarkan pedoman interpretasi koefisien korelasi termasuk kedalam hubungan yang sedang antara penglaman berbelanja terhadap minat beli.

Pengalaman berbelanja online yang dilakukan oleh konsumen akan memberikan dampak bagi konsumen itu sendiri di kemudian hari. Apabila pengalaman belanja yang dilakukan sebelumnya tidak baik, maka konsumen cenderung tidak akan mempunyai niat untuk berbelanja kembali. Hal tersebut sejalan dengan teori yang dikemukakan oleh (Ling et al, 2010) yang menjelaskan bahwa pengalaman berbelanja berpengaruh terhadap minat beli, yaitu "Jika pengalaman yang diterima konsumen ternyata memberikan rasa kepuasan, maka akan meningkatkan minat belinya dan akan membuat konsumen melakukannya lagi di masa depan. Namun, jika pengalaman negatif yang diterima maka pelanggan akan enggan untuk melakukannya lagi di masa depan”. Berdasarkan hasil dari perhitungan koefisien determinasi sebesar $31,36 \%$. Hal ini menunjukan bahwa pengaruh pengalaman berbelanja terhadap minat beli sebesar 31,36\% sementara 68,64\% dipengaruhi olah faktor lain. Hasil tersebut mengindikasikan jika pengalaman berbelanja memiliki dampak untuk meningkatkan minat beli pada situs belanja online. Kemudian berdasarkan uji t atau thitung diperoleh 6,56 dan ttabel diperoleh 1,66 dimana dari data tersebut menunjukan bahwa thitung $>$ ttabel $(6,56>1,66)$ maka hipotesis diterima, artinya terdapat pengaruh positif dan pada pengalaman berbelanja terhadap minat beli. Dengan demikian apabila pengalaman berbelanja konsumen terhadap situs belanja online itu baik, maka minat beli akan meningkat. Hal ini juga didukung oleh penelitian yang dilakukan (Yansya, 2018) bahwa pengalaman berbelanja berpengaruh positif terhadap minat beli.

Kepercayaan konsumen dan pengalaman berbelanja merupakan salah satu faktor penting yang dapat mempengaruhi minat beli seseorang dalam mengambil keputusan dalam berbelanja secara online. Ketika seseorang berbelanja online, hal utama yang menjadi pertimbangan seorang konsumen adalah apakah website yang menyediakan online shop tersebut terpercaya atau tidak. Kepercayaan konsumen terhadap minat beli pada situs belanja online berkaitan dengan kehandalan penjual online dalam menjamin keamanan bertransaksi dan dapat meyakinkan konsumen bahwa transaksi akan diproses setelah pembayaran dilakukan oleh konsumen. Kepercayaan merupakan salah satu faktor kritis dalam stimulant transaksi secara online. Saat kepercayaan konsumen semakin tinggi tentu akan dapat dijadikan ukuran untuk menumbuhkan minat beli konsumen secara online. Selain itu, konsumen dapat memperoleh pengalaman dengan melakukan pembelian kecil pada awalnya, setelah itu konsumen akan lebih 
mengembangkan kepercayaan diri dalam melakukan belanja secara online. Kepuasan pengalaman berbelanja yang dirasakan konsumen dapat membuat minat beli secara online meningkat dan akan menarik minat beli konsumen di masa depan. Namun, jika pengalaman negatif yang diterima maka konsumen akan enggan melakukan pembelian lagi. Hasil penelitian terhadap situs belanja online pada mahasiswa Fakultas Ekonomi Universitas Galuh menunjukan bahwa variabel kepercayaan konsumen dan pengalaman berbelanja berpengaruh positif terhadap variabel minat beli. Berdasarkan uji statistik perhitungan analisis korelasi berganda hubungan antara kepercayaan konsumen dan pengalaman berbelanja terhadap minat beli diperoleh angka sebesar 0,62, dimana berdasarkan pedoman interpretasi koefisien korelasi termasuk kedalam kategori hubungan yang kuat.

Kepercayaan konsumen dan pengalaman berbelanja sendiri memiliki peranan yang sangat penting untuk meningkatkan minat beli konsumen. Kepercayaan konsumen dan pengalaman berbelanja yang baik tentu akan mempengaruhi minat beli konsumen untuk berbelanja secara online sebab mereka yakin bahwa penjual mampu menjalakan kegiatan bisnisnya dengan baik. (Lee et al, 2011) juga mengemukakan bahwa "Kepercayaan berpengaruh positif terhadap minat beli pada situs jual beli online. Semakin tinggi tingkat kepercayaan konsumen terhadap situs jual beli online maka hal ini juga akan semakin berpengaruh positif terhadap minat beli konsumen tersebut. Oleh karena itu penting bagi situs belanja online untuk terus menjaga kepercayaan konsumen terhadap toko online-nya". Berdasarkan hasil dari perhitungan, presentase koefisien determinasi sebesar 38,44\%. Hal ini menunjukan bahwa pengaruh kepercayaan konsumen dan pengalaman berbelanja terhadap minat beli sebesar 31,36\% sementara 68,64\% dipengaruhi olah faktor lain. Hal ini mengindikasikan jika kepercayaan konsumen dan pengalaman berbelanja memiliki dampak untuk meningkatkan minat beli pada situs belanja online. Kemudian berdasarkan uji t atau thitung diperoleh 29,24 dan ttabel diperoleh 4,84 dimana dari data tersebut menunjukan bahwa $t_{\text {hitung }}>t_{\text {tabel }}(29,24>4,84)$ maka hipotesis diterima, artinya terdapat pengaruh positif dan signifikan pada kepercayaan konsumen dan pengalaman berbelanja terhadap minat beli. Dengan demikian apabila kepercayaan konsumen dan pengalaman berbelanja konsumen terhadap situs belanja online itu baik, maka minat beli akan meningkat. Hal ini juga didukung oleh peneliti yang dilakukan (Furi et al, 2020) yang menyatakan bahwa kepercaayaan dan pengalaman berbrlanja berpengaruh positif terhadap minat beli online pada situs jual beli Shopee.

\section{KESIMPULAN}

Kepercayaan konsumen terhadap minat beli pada situs belanja online di kalangan Mahasiswa Fakultas Ekonomi Universitas Galuh sudah dalam kategori baik, akan tetapi masih terdapat indikator rendah mengenai keandalan dalam situs belanja online. Oleh sebab itu, situs belanja online harus mampu meningkatkan keandalannya baik itu dari segi pelayanan agar lebih fast respond, meningkatkan kualitas produk yang dijual, serta memperhatikan kelengkapan stok barang sehingga konsumen akan lebih percaya ketika melakukan pembelian secara online dan minat beli konsumen akan meningkat. Pengalaman berbelanja terhadap minat beli pada situs belanja online di kalangan Mahasiswa Fakultas Ekonomi Universitas Galuh sudah dalam kategori baik, akan tetapi masih ada indikator yang rendah mengenai merasa berkompeten ketika berbelanja online. Oleh sebab itu, situs belanja online harus mampu meningkatkan kompetensi baik itu dalam segi pengemasan produk yang dibeli konsumen sehingga dalam proses pengiriman barang tersebut tidak memakan waktu yang lama dan sampai kepada konsumen sesuai dengan estimasi waktu yang diberikan sehingga konsumen mempunyai pengalaman yang lebih baik lagi ketika melakukan transaksi pembelian secara online dan minat beli konsumen akan meningkat. Kepercayaan konsumen dan pengalaman berbelanja terhadap minat beli pada situs belanja online di kalangan Mahasiswa Fakultas Ekonomi Universitas Galuh sudah dalam kategori baik, akan tetapi situs belanja online harus mampu meningkatkan jaminan produk yang sudah diterima konsumen apabila produk tersebut dalam keadaan rusak atau cacat dengan memberikan retur kepada konsumen. Karena, dengan terjaminnya produk sampai kepada konsumen dalam keadaan baik, maka akan meningkatkan minat beli pada situs belanja online tersebut sebab konsumen merasa percaya untuk melakukan transaksi pembelian dan mempunyai pengalaman berbelanja yang baik. 
Jurnal Value, 16 (2), Hal. 499 - 511

\section{SARAN}

Terdapat dua saran dari kegiatan penelitian yang terdiri dari saran praktis juga saran teoritis, saran tersebut dideskripsikan sebagai berikut:

1. Saran Praktis, Situs berbelanja online memiliki sistem yang cukup sederhana untuk dipahami baik oleh pembeli maupun penjual. Dengan kesederhanaan ini seluruh e-commerce diharapkan dapat menjaga keandalan pelayananya dengan tetap responsif dan dapat menyelesaikan seluruh keluahan pelanggan baik dari keluhan yang bersifat mudah hingga sulit. Selain itu, pihak pengelola e-commerce dapat mencantumkan deskripsi yang lebih detil seperti kelengkapan stok produk yang dijual. Adapun untuk menjaga pengalaman berbelanja, situs e-commerce perlu memiliki mitra yang memiliki kapabilitas dalam pengiriman barang, hal ini dikarenakan ketepatan waktu sampai produk di tangan konsumen merupakan konversi dari waktu antri pada gerai offline. Maka menjaga kerjasama dengan jasa ekspedisi menjadi salah satu alternatif untuk mempertahankan pengalaman berbelanja konsumen. Mempertahankan intensitas niat beli, para pengembang e-commerce perlu memberikan promosi menarik dengan intensitas yang cukup cepat, dengan ini maka konsumen akan mudah terstimulus oleh banyaknya ajakan dari perusahaan yang memberikan benefit diluar kebiasan.

2. Saran Teoritis, Dengan hasil penelitian ini melanjutkan pembangunan teori yang telah ada di bidang manajemen pemasaran dan dapat dijadikan sebagai salah satu sumber pustaka untuk penelitian selanjutnya yang dapat meneliti minat beli dengan variabel yang berbeda. Diharapkan adanya penelitian selanjutnya yang meneliti mengenai minat beli pada platform e-commerce yang lebih komprehensif seperti membahas mengenai UI/UX dari sebuah platform pembelajaan daring untuk mengembangkan teori-toeri pada perilaku konsumen. Hal ini dikarenakan pada saat ini teknologi dapat memberikan stimulus pada minat beli calon konsumen.

\section{REFERENSI}

Andromeda, Kevin. 2015. Analisis Pengaruh Kepercayaan, Kemudahan, dan Keragaman Produk Pakaian Via Online terhadap Keputusan Pembelian Secara Online. Skripsi pada Program Studi Manajemen Fakultas Ekonomi dan Bisnis Universitas Muhamadiyah Surakarta.

Astuti, Sri Rahayu Tri. 2010. Analisis Pengaruh Iklan, Kepercayaan Merek dan Citra Merek terhadap Minat Beli Konsumen. Skripsi pada Program Studi Manajemen Fakultas Ekonomika dan Bisnis Universitas Diponegoro.

Baskara, Isnain Putra dan Guruh Taufan Hariyadi. 2014. Analisis Pengaruh Kepercayaan, Keamanan, Kualitas Pelayanandan Persepsi Akan Resiko terhadap Keputusan Pembelian Melalui Situs Jejaring Sosial (Social Networking Websites). Skripsi pada Program Studi Manajemen Fakultas Ekonomi dan Bisnis Universitas Dian Nuswantoro.

Durianto. 2013. Strategi Menaklukkan Pasar Melalui Rset Ekuitas dan Perilaku Merek. Jakarta: Penerbit Gramedia Pustaka Utama

Ferdinand, Augusty, 2002, Pengembangan Minat Beli Merek Ekstensi, Semarang: Badan Penerbit Universitas Diponegoro

Firdayanti, R. 2012. Persepsi Risiko Melakukan E-commerce dengan Kepercayaan Konsumen Dalam Membeli Produk Fashion Online. Journal of Social and Industrial Psychology. 1(1). 1-7.

Furi, Ratna., et. al. 2020. Pengaruh Keamanan, Kemudahan, Kepercayaan dan Pengalaman Berbelanja terhadap Minat Beli Online pada Situs Jual Beli Shopee. jurnal ilmiah riset manajemen. 9(2). 96-109.

Ikranegara, Dikla Purbayudya. 2017. Pengaruh Orientasi Belanja, Kepercayaan Online, dan Pengalaman Pembelian Terhadap Minat Beli Secara Online. Skripsi pada Program Studi Manajemen Fakultas Ekonomi Universitas Negeri Yogyakarta

Jalilvand, R. 2013. The Effect of Electronic Word of Mouth on Brand Image and Purchase Intention. Journal of Intelegence and Planning. 30 (4). 460- 476. 
Jurnal Value, 16 (2), Hal. 499 - 511

Kotler, Philip dan Kevin Lane Keller. 2012. Marketing Management. Edisi 14. Global Edition. Pearson Prentice Hall.

Laudon, Kenneth C and Carol Travel Guercio. 2015. E-Commerce: Business, Technology, Society. USA: Prentice Hall.

Lee Yu, P., dan Jyh, Shen, C. 2011. 'How Much Can You Trust Online Information? Cues for Perceived Trust-worthiness of Consumer-generated Online Information'. Journal of Interactive Marketing, Vol.25 page 67-74.

Ling, Kwek Choon, Lau Teck Chai \& Tan Hoi Piew. 2010. The Effects of Shopping Orientations, Online Trust and Prior Online Purchase Experience toward Customers Online Purchase Intention. Journal of International Business Research. 3(3). 63-76.

Mowen, Hansen. 2011. Akuntasi Manajerial Buku 2 Edisi kedelapan. Jakarta: Salemba Empat

Paramasatya, Eriandi. 2018. Pengaruh Pengalaman Berbelanja dan Kepercayaan Konsumen terhadap Minat Beli Konsumen pada Situs Jual Beli Online Tokopedia.Com. Skripsi pada Program Studi Manajemen Fakultas Ekonomi Universitas Darma Persada.

Priansa, Doni Junni. 2017. Manajemen Pelayanan Prima. Bandung: Alfabeta

Putri, Deliana Mahyani. 2016. Pengaruh Online Shopping Enjoyment dan Kepercayaan Konsumen terhadap Minat Pembelian Produk Fashion Hijab di Social Commerce. Skripsi pada Fakultas Ekonimi dan Bisnis Universitas Pendidikan Indonesia.

Rosdiana, Riski dan Akhmad Haris, Iyus. 2018. Pengaruh Kepercayaan Konsumen Terhadap Minat Beli Produk Pakaian Secara Online. International journal of Social science and Busniess. Volume 3 Nomor 3. 169-175. 10.23887/ijssb.v2i3.16240.

Schiffman, L.G. dan Kanuk, L.L. 2010. Consumer Behaviour. Edisi kesepuluh. New Jersey: Pearson Prentice Hall

Schmitt, Bernd. 2010. Experience Marketing: Concepts, Frameworks and Consumer Insights. Foundations and Trends in Marketing Vol 5 No 2, 2010. DOI: 10.1561/1700000027

Sumarwan, Ujang. 2013. Riset Pemasaran Dan Konsumen. Bogor: Edisi II. IPB Press.

Sumarwan, Ujang. 2015. Perilaku Konsumen Teori Penerapannya Dalam Pemasaran. Edisi Kedua. Bogor: Cetakan Ketiga. Penerbit Ghalia Indonesia

Wong, Jony. 2010. Internet Marketing for Beginners. Jakarta: PT Elex Media Komputindo

Yansya, Rendi. 2018. Pengaruh Kemudahan Pengguanaan, Pengalaman Berbelanja dan Kepercayaan Konsumen terhadap Minat Beli Konsumen di Situs Jual Beli Online Shopee di Kota Jambi. Skripsi pada Program Studi Ekonomi Syariah Fakultas Ekonomi dan Bisnis Islam Universitas Islam Negeri Sulthan Thaha Saifuddin. Repository Uin Jambi. 